\title{
Anti-Oxidative Potential of Biofield Energy Treatment on Lung Health Using A549 Cells
}

\author{
Alice Branton ${ }^{1}$ and Snehasis Jana ${ }^{2 *}$ \\ ${ }^{1}$ Trivedi Global, Inc., Henderson, USA \\ ${ }^{2}$ Trivedi Science Research Laboratory Pvt. Ltd., Bhopal, India
}

*Corresponding author: Snehasis Jana, Trivedi Science Research Laboratory Pvt. Ltd., Bhopal, India, Email: publication@trivedisrl.com

\section{Research Article}

Volume 3 Issue 5

Received Date: November 22, 2018

Published Date: December 10, 2018

DOI: $10.23880 /$ apct- 16000145

\section{Abstract}

Oxidative stress plays a crucial role in most of the diseases and their complications. The present investigation was undertaken to evaluate the anti-oxidative potential of Consciousness Energy Healing Treated DMEM medium on the level of protection against oxidative stress and superoxide dismutase (SOD) enzyme activity using A549 cells. The test item (DMEM) was divided into two parts. One portion was denoted as the untreated DMEM without any Biofield Energy Treatment, while the other portion was defined as the Biofield Energy Treated DMEM, which received the Biofield Energy Healing Treatment by a renowned Biofield Energy Healer, Alice Branton. The cell viability of the test items using MTT assay showed an increase viable cells by $122.60 \%$ in the Biofield Energy Treated DMEM, suggesting a safe and nontoxic profile of the test items. Furthermore, the cellular protection against oxidative stress was significantly increased by $60.50 \%$ in the Biofield Energy Treated DMEM group compared with the untreated DMEM group. Additionally, the SOD enzyme activity was significantly increased by $38.08 \%$ in the Biofield Energy Treated DMEM group compared with the untreated DMEM group. Thus, the overall in vitro lung health data suggest that the Consciousness Energy Healing Treatment showed a significant improvement of anti-oxidative potential against oxidative damage caused by free radicals and stress in A549 cells. It is concluded that the Biofield Energy Healing Treatment has the significant capacity to increase the SOD enzyme level (antioxidant activity) along with an improved cellular protection against oxidative damage. Thus, The Trivedi Effect ${ }^{\circledR}$ can be used in various human lung disorders such as asthma, chronic obstructive pulmonary disease (COPD), lung malignancies and parenchymal lung diseases like idiopathic pulmonary fibrosis and lung granulomatous diseases.

Keywords: Biofield Energy; SOD; Oxidative stress; A549 cell; DMEM; Lung disorder

Abbreviations: CAM: Complementary and Alternative Medicine; NCCAM: National Center for Complementary and Alternative Medicine; NIH: National Institute of Health; ANOVA: One-way analysis of variance; DMEM: Dulbecco's Modified Eagle's Medium; FBS: Fetal Bovine 


\section{Advances in Pharmacology and Clinical Trials}

Serum; CD-FBS: Charcoal dextran stripped FBS; SOD: Superoxide dismutase; COPD: Chronic obstructive pulmonary disease; ROS: Reactive oxygen species; RNS: Reactive nitrogen species.

\section{Introduction}

Oxidants play a major contribution in the disease pathogenesis of organ systems such as the lung and pulmonary vasculature. Oxidative stress can lead to an increase production of free radicals in the respiratory system causing pulmonary inflammation and promotes the process of carcinogenesis [1]. Oxidative damage is considered a pivotal role in aging, several degenerative diseases and cancer [2]. Oxidative stress in the respiratory system increases the production of mediators of pulmonary inflammation and initiate or promote the mechanisms of carcinogenesis [1]. The primary free radicals are produced during stress conditions like reactive oxygen species (ROS) and reactive nitrogen species (RNS) that lead to the imbalance between the oxidants and endogenous antioxidants. This imbalance can increase the levels of ROS and RNS, which significantly alters the structural property of lipids, DNA, carbohydrates, and proteins [3]. Lung diseases are highly profound with the change in endogenous oxidantantioxidant systems, as they were highly exposed by various oxidants i.e., endogenous and exogenous oxidants (cigarette smoke, mineral dust, ozone, and radiation) [4]. Lung diseases pathogenesis involves the role of oxidative stress in case of asthma, chronic obstructive pulmonary disease (COPD), lung malignancies and parenchymal lung diseases like idiopathic pulmonary fibrosis and lung granulomatous diseases [5]. Endogenous antioxidants of the body such as in lung tissue have the capacity to fight against these external and internal oxidants through various antioxidant mechanisms. One of the best effective defense mechanisms in lung cells is superoxide dismutase (SOD) enzyme, which significantly effective against free radicals and converts superoxide radicals to the hydrogen peroxide. SOD enzyme protects from various types of oxidative stress and play a vital role in protecting the lung tissues and other body tissues. However, very few studies have been reported on SOD level in the normal human lung for protecting the lung health. To combat the oxidants damage against oxidative stress and improved SOD enzyme in lung tissues would be the best approach towards lung health [6,7]. Hence, in the present study, A549 (lung adenocarcinoma) cells were used to study the effect of the Biofield Energy Treated DMEM media as a test item on lung health using SOD and oxidative damage protection as biomarkers.
Numerous scientific reports in recent years along with the clinical trials have discovered the beneficial role of Biofield Energy Treatment to improve the overall Quality of Life. Biofield Energy Healing Therapies are characterized under Complementary and Alternative Medicine (CAM), which have been reported to have a significant impact on living organisms and non-living materials. National Centre for Complementary and Alternative Medicine (NCCAM)/ National Institute of Health (NIH) approved CAM as an alternative treatment in health care sector [8]. Biofield Energy Healing Treatment has significant benefits in various scientific fields. The effects of the CAM therapies have great potential, which include Johrei, Reiki, therapeutic touch, yoga, Qi Gong, polarity therapy, Tai Chi, pranic healing, deep breathing, chiropractic/osteopathic manipulation, guided imagery, meditation, massage, homeopathy, hypnotherapy, progressive relaxation, acupressure, acupuncture, special diets, relaxation techniques, Rolfing structural integration, healing touch, movement therapy, pilates, mindfulness, Ayurvedic medicine, traditional Chinese herbs and medicines in biological systems [9]. The Trivedi Effect ${ }^{\circledR}$ contains a putative bioenergy, which is channeled by a renowned Biofield practitioner from a short distance as well as remotely. Biofield Energy Healing as a CAM showed a significant result in biological studies [10]. However, the NCCAM well-defined that the Biofield Therapies is in the subcategory of Energy Therapies [11]. The Trivedi Effect ${ }^{\circledR}$ - Consciousness Energy Healing Treatment has been reported with significant revolt in the physicochemical properties of metals, chemicals, ceramics and polymers [12-14], an improved agricultural crop yield, productivity, and quality $[15,16]$, transformed antimicrobial characteristics [1719], biotechnology $[20,21]$, an improved bioavailability [22-24], skin health [25,26], nutraceuticals [27,28], cancer research [29,30], bone health [31-33], human health and wellness. On the basis of Biofield Energy Treatment outcome, authors in this study evaluated the impact of the Biofield Energy Treated (The Trivedi Effect ${ }^{\circledR}$ ) DMEM as the test sample for its lung health potential with respect to SOD and oxidative stress as biomarkers using the standard in vitro assay in A549 cells (lung adenocarcinoma).

\section{Material and Methods}

\section{Chemicals and Reagents}

Quercetin was purchased from Alfa Aesar, India. Fetal bovine serum (FBS) and Dulbecco's Modified Eagle's Medium (DMEM) were purchased from Life Technology, USA. $t$-BHP (tert-butyl hydroperoxide) was purchased 


\section{Advances in Pharmacology and Clinical Trials}

from Sigma, India. Antibiotics solution (penicillinstreptomycin) was procured from HiMedia, India, while 3(4, 5-dimethyl-2-thiazolyl)-2, 5-diphenyl-2H-tetrazolium) (MTT), Direct Red 80, and ethylenediaminetetraacetic acid (EDTA) were purchased from Sigma, USA. All the other chemicals used in this experiment were analytical grade procured from India.

\section{Cell Culture}

A549 (lung adenocarcinoma) from muscle tissue of Mus musculus was used as the test system in the present study. Ishikawa cell line was maintained in DMEM growth medium for routine culture supplemented with 10\% FBS. Growth conditions were maintained at $37^{\circ} \mathrm{C}, 5 \% \mathrm{CO}_{2}$, and 95\% humidity and sub-cultured by trypsinisation followed by splitting the cell suspension into fresh flasks and supplementing with fresh cell growth medium. Before the start of the experiment, the growth medium of nearconfluent cells was replaced with fresh phenol-free DMEM, supplemented with 10\% charcoal-dextran stripped FBS (CD-FBS) and 1\% penicillin-streptomycin for 3 days [34].

\section{Experimental Strategy}

The experimental groups consisted of group 1 (G-I) with cells in baseline control with DMEM. Group 2 (G-II) consisted of positive control at non-cytotoxic concentrations. Further, group 3 (G-III) included the Biofield Energy Treated DMEM.

\section{Consciousness Energy Healing Treatment Strategies}

The test item, DMEM was divided into two parts, one part was treated with the Biofield Energy by a renowned Biofield Energy Healer (The Trivedi Effect ${ }^{\circledR}$ ), Alice Branton remotely for $\sim 5$ minutes and coded as the Biofield Energy Treated DMEM, and the other part did not receive any sort of treatment and denoted as the untreated DMEM. The Biofield Energy Healer was located in the USA, while the test item was located in the research laboratory of Dabur Research Foundation, New Delhi, India. This Biofield Energy Treatment was administered through the Healer's unique Energy Transmission process remotely to the test sample under laboratory conditions. Biofield Energy healer in this study never visited the laboratory in person, nor had any contact with the test item. Further, the untreated DMEM (control) group was treated with "sham" healer for comparative purposes. The "sham" healer did not have any knowledge about the Biofield Energy Treatment. After that, the Biofield Energy
Treated and untreated samples were kept in similar sealed conditions for experimental study.

\section{Identification of Non-cytotoxic Concentration}

The cell viability was performed by MTT assay in lung adenocarcinoma cell line (A549). The cells were counted and plated in 96-well plates at the density corresponding to $10 \times 10^{3}$ cells/well/180 $\mu \mathrm{L}$ of cell growth medium. The above cells were incubated overnight under growth conditions and allowed the cell recovery and exponential growth, which were subjected to serum stripping or starvation. The cells were treated with the test item (DMEM) and positive control. The cells in the above plate(s) were incubated for 24 hours in a $\mathrm{CO}_{2}$ incubator at $37^{\circ} \mathrm{C}, 5 \% \mathrm{CO}_{2}$, and $95 \%$ humidity. Following incubation, the plates were taken out and $20 \mu \mathrm{L}$ of $5 \mathrm{mg} / \mathrm{mL}$ of MTT solution were added to all the wells followed by additional incubation for 3 hours at $37^{\circ} \mathrm{C}$. The supernatant was aspirated and $150 \mu \mathrm{L}$ of DMSO was added to each well to dissolve formazan crystals. The absorbance of each well was read at $540 \mathrm{~nm}$ using Synergy HT microplate reader, Bio Tek, USA [35]. The percentage cytotoxicity at each tested concentrations of the test substance were calculated using the following equation (1):

$$
\% \text { Cytotoxicity }=(1-\mathrm{X} / \mathrm{R}) * 100
$$

Where, $\mathrm{X}=$ Absorbance of treated cells; $\mathrm{R}=$ Absorbance of untreated cells

The percentage cell viability corresponding to each treatment was obtained using the following equation (2):

$\%$ Cell Viability = $100-\%$ Cytotoxicity

The concentrations exhibiting $\geq 70 \%$ cell viability was considered as non-cytotoxic.

\section{Effect of Test Item's Protection Effect against Oxidative Damage}

The A549 cells were counted using a hemocytometer and plated in 96-well plates at the density corresponding to $1 \times 10^{4}$ cells/well followed by overnight incubation in a $\mathrm{CO}_{2}$ incubator at $37^{\circ} \mathrm{C}, 5 \% \mathrm{CO}_{2}$, and $95 \%$ humidity. Following overnight incubation, the cells were treated with the positive control and test item. To induce oxidative damage, co-treatment with $t$-BHP $(150 \mu \mathrm{M})$ was added. The cells corresponding to the positive control group were treated with quercetin. The untreated cells served as negative control [36]. After incubation, the plates were taken out and the percentage cell viability 


\section{Advances in Pharmacology and Clinical Trials}

corresponding to each treatment group was calculated using the following equation (3):

$$
\begin{aligned}
& \% \text { Protection }=[\text { Absorbance } \text { sample } \text {-Absorbance } t \text { - } \\
& \text { BHP })]^{*} 100 /\left[\text { Absorbance }_{\text {untreated }} \text {-Absorbance } \text { t_BHP }_{-}\right]-(3)
\end{aligned}
$$

\section{Evaluation of Intracellular Superoxide Dismutase (SOD) Enzyme Activity}

The A549 cells were counted using a hemocytometer and plated in 24-well plates at the density corresponding to $2 \mathrm{X} 10^{4}$ cells/well followed by overnight incubation in a $\mathrm{CO}_{2}$ incubator at $37^{\circ} \mathrm{C}, 5 \% \mathrm{CO}_{2}$, and $95 \%$ humidity. Following overnight incubation, the cells were treated with the positive control and test item. To induce oxidative damage, co-treatment with $t$-BHP $(150 \mu \mathrm{M})$ was added. The cells corresponding to positive control group were treated with quercetin. The untreated cells served as negative control. After 24 hours of treatment, cell lysates were prepared by freeze-thaw lysis. SOD activity of the cells was assessed using cayman superoxide dismutase assay kit as per manufacturer's protocol. Further, $10 \mu \mathrm{L}$ of the standard or the sample was added to $200 \mu \mathrm{L}$ of radical detector in a designated well on the plate. Reaction was initiated using xanthine oxidase $(20 \mu \mathrm{L})$ in all the wells. After 30 minutes of incubation on shaker, absorbance was read at $450 \mathrm{~nm}$ using Synergy HT microplate reader. SOD activity of the samples was calculated using linear regression equation of the standard curve [37]. However, the percentage increase in SOD activity with respect to the $t$-BHP was calculated as per equation (4)-

Percentage increase $=\left[\left(\mathrm{SOD}_{\text {sample }^{-}} \mathrm{SOD}_{\mathrm{tBHP}}\right) /\left(\mathrm{SOD}_{\text {untreated }^{-}}\right.\right.$

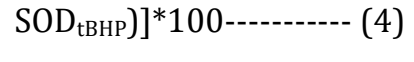

\section{Statistical Analysis}

All the values were represented as Mean \pm SEM of three independent experiments. For multiple group comparison, one-way analysis of variance (ANOVA) was used followed by post-hoc analysis by Dunnett's test. Statistically significant values were set at the level of $p \leq 0.05$.

\section{Results and Discussion}

\section{Cell Viability Using MTT Assay}

The test samples (untreated and Biofield Treated DMEM) were initially screened for the determination of non-cytotoxic concentration using MTT cytotoxicity assay, and the data are shown in Figure 1. The MTT data showed that the test samples were found to have significant cell viability with $122.60 \%$ in the Biofield Energy Treated
DMEM group, while more than $72 \%$ in the quercetin (positive control) group at various concentrations. Overall, the MTT data suggested that The Trivedi Effect ${ }^{\circledR}$ Biofield Energy Healing treated DMEM was found to be safe and nontoxic in the tested concentration in A549 cells as compared with the untreated DMEM group.

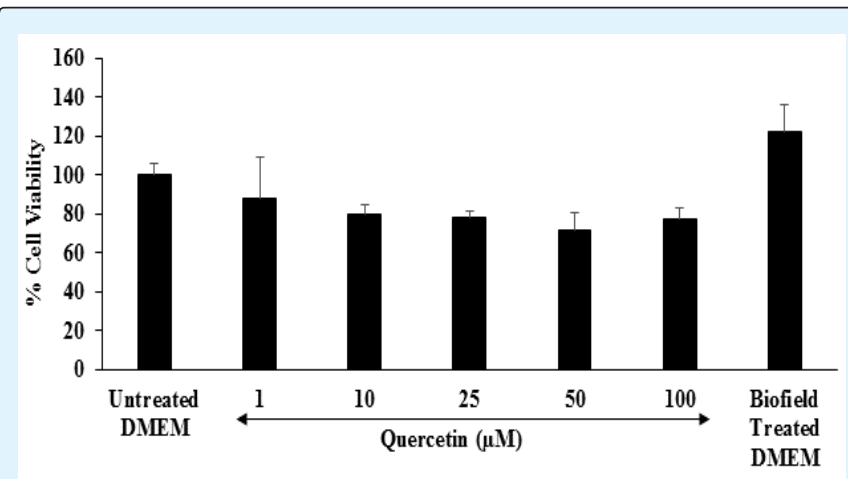

Figure 1: Determination of non-cytotoxic concentration of quercetin and DMEM in A549 cells using MTT assay. Values were expressed as Mean \pm SEM of three independent assay.

\section{Assessment of Cellular Protection against Oxidative Damage}

The anti-oxidative activity of the test samples against $t$-BHP induced oxidative stress in A549 cells is shown in Figure 2. Protection against oxidative stress in terms of percentage values was described and compared with the untreated DMEM (control) group. The positive control, quercetin showed a significantly $(p \leq 0.001)$ increase cellular protection by $20.12 \%, 35.97 \%$, and $57.95 \%$ at 1 , 10 , and $50 \mu \mathrm{M}$, respectively with respect to the untreated DMEM group. The Biofield Energy Treated DMEM group showed a significant $(p \leq 0.001)$ increase cellular protection against oxidative damage by $60.50 \%$ compared with the untreated DMEM group. This suggests that Biofield Energy Treatment has the significant capacity to reduce the oxidative stress, which can create a balance between the oxidants and antioxidants. Any inflammatory diseases or autoimmune diseases cause severe stress and production of free radicals, which would damage the cells, cellular processes, lipids, DNA, carbohydrates, and proteins [38]. $t$-BHP has the significant capacity to reduce the cell viability and causes cell death. ROS can interact with cellular proteins, lipids or DNA, cell dysfunction, and cause apoptosis. This implicating severe oxidative damage leads to various disease pathogenesis [39]. However, the Biofield Energy Healing Treatment might significantly improve the protection level against oxidative damage 


\section{Advances in Pharmacology and Clinical Trials}

that leads to a better lung health against many lung diseases.

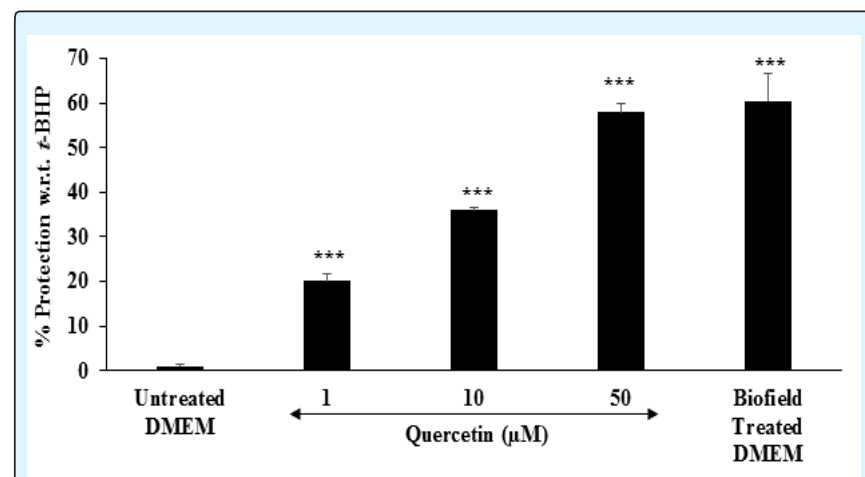

Figure 2: Protective effect of the untreated and Biofield Energy Treated DMEM against oxidative stress induced by tert-butyl hydroperoxide ( $t$-BHP) on A549 cells. Data were expressed as Mean \pm SEM of three independent experiments. ${ }^{* * *} p \leq 0.001$ compared to the untreated DMEM group.

\section{Superoxide Dismutase (SOD) Enzyme Activity}

The antioxidant enzyme superoxide dismutase (SOD) has been considered as a biomarker in lung health studies and associated human lung disorders. During inflammation, asthmatic airways, and in parenchymal lung diseases, the level of SOD is down regulated, which can be due to an increased level of free radicals and reduced antioxidant activity of lung and airways. The SOD level can be maintained using various types of antioxidants that are used to improve the level of antioxidant enzymes and reduce the level of free radicals $[40,41]$. In the present study, SOD enzyme activity was measured for the test samples and positive control in A549 cells, and the data are shown in Figure 3. The results are presented in terms of the percentage of SOD enzyme activity with respect to $t$-BHP. The positive control, quercetin showed a significantly increase cellular protection by $35.76 \%, 66.79 \%$, and $121.13 \%$ at $0.25,0.5$, and $1 \mu \mathrm{M}$, respectively with respect to the untreated DMEM (control) group. The Biofield Energy Treated DMEM group showed a significant increase level of SOD enzyme by $38.10 \%$ compared with the untreated DMEM group. Thus, the current study revealed that the Biofield Energy Treatment has the significant capacity to work as an antioxidant and to reduce the free radicals that play a vital role in the management of lung health and human lung diseases.

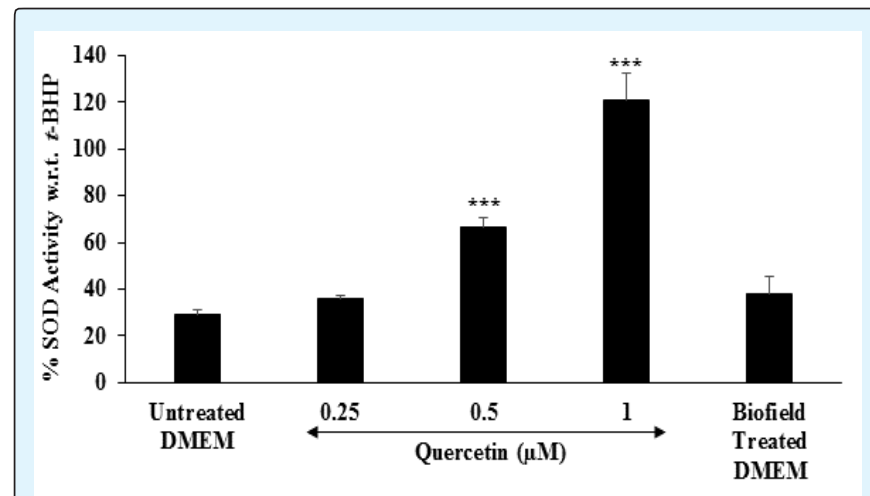

Figure 3: Superoxide dismutase (SOD) enzyme activity of the quercetin and Biofield Energy Treated DMEM on A549 cells. Data were expressed as Mean \pm SEM of three independent experiments. ${ }^{* * *} p \leq 0.001$ compared to the untreated DMEM group.

\section{Conclusions}

The cell viability using MTT assay showed 122.60\% viable cells in the Biofield Treated DMEM group, suggesting a safe and nontoxic nature of the test item. Further, the cellular protection level against oxidative stress and the level of antioxidant enzyme SOD were significantly increased by $60.50 \%$ and $38.08 \%$ respectively, in the Biofield Energy Treated DMEM group compared with the untreated DMEM group. Thus, the result suggests that the Biofield Energy Treated (The Trivedi Effect ${ }^{\circledR}$ ) DMEM showed a significant impact to protect from oxidative damage of human lung adenocarcinoma cells (A549). It can also be utilized for the management of various human lung disorders such as Asbestosis, Bronchiectasis, Bronchitis, Chronic Cough, Chronic Obstructive Pulmonary Disease (COPD), Common Cold, Cystic Fibrosis, Hantavirus, Idiopathic Pulmonary Fibrosis, Influenza, Lung Cancer, Pandemic Flu, Pertussis, Pleurisy, Pneumonia, Pulmonary Embolism, Respiratory Syncytial Virus (RSV), Sarcoidosis, Sleep Apnea, Sudden Infant Death Syndrome (SIDS), Tuberculosis, and WorkRelated Asthma. Besides, it may also control the immune related disease conditions such as Hashimoto Thyroiditis, Aplastic Anemia, Hepatitis, Diverticulitis, Pernicious Anemia, Sjogren Syndrome, Myasthenia Gravis, Parkinson's Disease, Asthma, Graves' Disease, Dermatomyositis, Multiple Sclerosis, Ulcerative Colitis, Alzheimer's Disease, Dermatitis, Irritable Bowel Syndrome, Diabetes, Atherosclerosis, Systemic Lupus Erythematosus, stress, etc. with a safe therapeutic index to improve overall health, and Quality of Life. 


\section{Advances in Pharmacology and Clinical Trials}

\section{Acknowledgement}

The authors would like to acknowledge the research support of Dabur Research Foundation, Trivedi Global, Inc., Trivedi Science, Trivedi Testimonials, and Trivedi Master Wellness for their throughout the work.

\section{References}

1. Boots AW, Haenen GR, Bast A (2003) Oxidant metabolism in chronic obstructive pulmonary disease. Eur Respir J 46: 14-27.

2. Kinnula VL, Crapo JD, Raivio KO (1995) Generation and disposal of reactive oxygen metabolites in the lung. Lab Invest 73(1): 3-19.

3. Pham-Huy LA, He H, Pham-Huy C (2008) Free radicals, antioxidants in disease and health. Int J Biomed Sci 4(2): 89-96.

4. Romieu I (2005) Nutrition and lung health. Int J Tuberc Lung Dis 9(4): 362-374.

5. Kelly FJ (2005) Vitamins and respiratory disease: antioxidant micronutrients in pulmonary health and disease. Proc Nutr Soc 64(4): 510-526.

6. Crapo JD, Tierney DF (1974) Superoxide dismutase and pulmonary oxygen toxicity. Am J Physiol 226(6): 1401-1407.

7. Valavanidis A, Vlachogianni T, Fiotakis K, Loridas S (2013) Pulmonary oxidative stress, inflammation and cancer: respirable particulate matter, fibrous dusts and ozone as major causes of lung carcinogenesis through reactive oxygen species mechanisms. Int J Environ Res Public Health 10(9): 3886-3907.

8. Rubik B, Muehsam D, Hammerschlag R, Jain S (2015) Biofield science and healing: History, terminology, and concepts. Glob Adv Health Med 4: 8-14.

9. Rubik B (2002) The biofield hypothesis: Its biophysical basis and role in medicine. J Altern Complement Med 8(6): 703-717.

10. Barnes PM, Bloom B, Nahin RL (2008) Complementary and alternative medicine use among adults and children: United States, 2007. Natl Health Stat Report 12: 1-23.

11. Frass M, Strassl RP, Friehs H, Müllner M, Kundi M, et al. (2012) Use and acceptance of complementary and alternative medicine among the general population and medical personnel: A systematic review. Ochsner J 12(1): 45-56.

12. Trivedi MK, Tallapragada RM (2008) A transcendental to changing metal powder characteristics. Met Powder Rep 63(9): 22-28, 31.

13. Trivedi MK, Nayak G, Patil S, Tallapragada RM, Latiyal 0 (2015) Studies of the atomic and crystalline characteristics of ceramic oxide nano powders after bio field treatment. Ind Eng Manage 4: 161.

14. Trivedi MK, Nayak G, Patil S, Tallapragada RM, Latiyal 0 , et al. (2015) Effect of biofield energy treatment on physical and structural properties of calcium carbide and praseodymium oxide. International Journal of Materials Science and Applications 4(6): 390-395.

15. Trivedi MK, Branton A, Trivedi D, Nayak G, Mondal SC, et al. (2015) Morphological characterization, quality, yield and DNA fingerprinting of biofield energy treated alphonso mango (Mangifera indica L.). Journal of Food and Nutrition Sciences 3(6): 245-250.

16. Trivedi MK, Branton A, Trivedi D, Nayak G, (2015) Evaluation of biochemical marker - Glutathione and DNA fingerprinting of biofield energy treated Oryza sativa. American Journal of Bio Science 3(6): 243-248.

17. Trivedi MK, Branton A, Trivedi D, Nayak G, Charan S, et al. (2015) Phenotyping and 16S rDNA analysis after biofield treatment on Citrobacter braakii: A urinary pathogen. J Clin Med Genom 3: 129.

18. Trivedi MK, Patil S, Shettigar H, Mondal SC, Jana S (2015) Evaluation of biofield modality on viral load of Hepatitis B and C viruses. J Antivir Antiretrovir 7: 8388.

19. Trivedi MK, Patil S, Shettigar H, Mondal SC, Jana S (2015) An impact of biofield treatment: Antimycobacterial susceptibility potential using BACTEC 460/MGIT-TB System. Mycobact Dis 5(4): 189.

20. Trivedi MK, Patil S, Shettigar H, Bairwa K, Jana S (2015) Phenotypic and biotypic characterization of Klebsiella oxytoca: An impact of biofield treatment. J Microb Biochem Technol 7: 203-206.

21. Nayak G, Altekar N (2015) Effect of biofield treatment on plant growth and adaptation. J Environ Health Sci 1: $1-9$. 


\section{Advances in Pharmacology and Clinical Trials}

22. Branton A, Jana S (2017) The influence of energy of consciousness healing treatment on low bioavailable resveratrol in male Sprague Dawley rats. International Journal of Clinical and Developmental Anatomy 3: 9-15.

23. Branton A, Jana S (2017) The use of novel and unique biofield energy healing treatment for the improvement of poorly bioavailable compound, berberine in male Sprague Dawley rats. American Journal of Clinical and Experimental Medicine 5: 138144.

24. Branton A, Jana S (2017) Effect of the biofield energy healing treatment on the pharmacokinetics of 25hydroxyvitamin D3 [25(OH)D3] in rats after a single oral dose of vitamin D3. American Journal of Pharmacology and Phytotherapy 2: 11-18.

25. Kinney JP, Trivedi MK, Branton A, Trivedi D, Nayak G, et al. (2017) Overall skin health potential of the biofield energy healing based herbomineral formulation using various skin parameters. American Journal of Life Sciences 5: 65-74.

26. Singh J, Trivedi MK, Branton A, Trivedi D, Nayak G, et al. (2017) Consciousness energy healing treatment based herbomineral formulation: A safe and effective approach for skin health. American Journal of Pharmacology and Phytotherapy 2(1): 1-10.

27. Trivedi MK, Branton A, Trivedi D, Nayak G, Plikerd WD, et al. (2017) A systematic study of the biofield energy healing treatment on physicochemical, thermal, structural, and behavioral properties of magnesium gluconate. International Journal of Bioorganic Chemistry 2(3): 135-145.

28. Trivedi MK, Branton A, Trivedi D, Nayak G, Plikerd WD, et al. (2017) Chromatographic and spectroscopic characterization of the consciousness energy healing treated Withania somnifera (ashwagandha) root extract. European Journal of Biophysics 5(2): 38-47.

29. Trivedi MK, Patil S, Shettigar H, Mondal SC, Jana S (2015) The potential impact of biofield treatment on human brain tumor cells: A time-lapse video microscopy. J Integr Oncol 4: 141.

30. Trivedi MK, Patil S, Shettigar H, Gangwar M, Jana S (2015) In vitro evaluation of biofield treatment on cancer biomarkers involved in endometrial and prostate cancer cell lines. J Cancer Sci Ther 7: 253257.
31. Weekes BA, Trivedi MK, Branton A, Trivedi D, Nayak G, et al. (2018) An alternative approach for the management of bone health: Role of biofield energy healing treated vitamin D3. American Journal of Internal Medicine 6(1): 1-9.

32. Nykvist CD, Trivedi MK, Branton A, Trivedi D, Nayak G, et al. (2018) A perspective of bone health study: Impact of biofield energy treated vitamin D3. International Journal of Clinical and Experimental Medical Sciences 4(1): 5-13.

33. Vannes VL, Trivedi MK, Branton A, Trivedi D, Nayak G, et al. (2018) Regulation of bone health parameters after treatment with biofield energy healing based vitamin D3 on human osteoblast cell line (MG-63). American Journal of Biomedical and Life Sciences 6(1): 24-32.

34. Czekanska EM, Stoddart MJ, Richards RG, Hayes JS (2012) In search of an osteoblast cell model for in vitro research. Eur Cells Mater 24: 1-17.

35. ISO (2009) Biological evaluation of medical devicesPart 5: Tests for in vitro cytotoxicity (ISO 109935:2009), I.S.EN ISO, 10993-5: 20093.

36. Tobwala S, Fan W, Hines CJ, Folk WR, Ercal N (2014) Antioxidant potential of Sutherlandia frutescens and its protective effects against oxidative stress in various cell cultures. BMC Complement Altern Med 14: 271 .

37. Weydert CJ, Cullen JJ (2010) Measurement of superoxide dismutase, catalase, and glutathione peroxidase in cultured cells and tissue. Nat Protoc 5: 51-66.

38. Cheresh P, Kim SJ, Tulasiram S, Kamp DW (2013) Oxidative stress and pulmonary fibrosis. Biochim Biophys Acta 1832(7): 1028-1040.

39. Lu LY, Ou N, Lu QB (2013) Antioxidant induces DNA damage, cell death and mutagenicity in human lung and skin normal cells. Sci Rep 3: 3169.

40. Rahman I (2006) Antioxidant therapies in COPD. Int J Chron Obstruct Pulmon Dis 1(1): 15-29.

41. Kinnula VL, Crapo JD (2003) Superoxide dismutases in the lung and human lung diseases. Am J Respir Crit Care Med 167(12): 1600-1619. 